\title{
A rare case: Renal cell carcinoma metastasis to lower lip
}

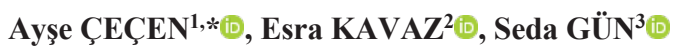 \\ ${ }^{1}$ Department of Otolaryngology, Samsun Training and Research Hospital, Samsun, Turkey \\ ${ }^{2}$ Department of Otolaryngology, Faculty of Medicine, Ondokuz Mayıs University, Samsun, Turkey \\ ${ }^{3}$ Department of Pathology, Faculty of Medicine, Ondokuz Mayıs University, Samsun, Turkey
}

\begin{abstract}
\begin{tabular}{ccccc}
\hline Received: $03.01 .2021 \quad \bullet \quad$ Accepted/Published Online: 30.01 .2021 & $\bullet$ & Final Version: 23.04 .2021
\end{tabular}
\section{Abstract}

Approximately $15 \%$ of renal cell carcinomas metastasize to the head and neck region. Here in, we report a rare case report of a patient who underwent nephrectomy for renal cell carcinoma (RCC) ten years ago and presented with metastatic renal cell carcinoma on her lower lip. A 65year-old woman presented with a rapidly growing mass on the lower lip. Pathology report resulted in renal cell carcinoma metastasis. Although metastatic renal cell carcinoma to the head and neck is uncommon, metastasis should be considered in the differential diagnosis of a rapidly growing vascular lesion in the head and neck area of patients with renal cell carcinoma.
\end{abstract}

Keywords: lip, metastasis, renal cell carcinoma, hemorrhage

\section{Introduction}

Renal cell carcinoma (RCC) is the most common malignant tumor of the kidney, typically affects men between the ages of 30 to 60 years (Gottlieb and Roland, 1998). Renal cell carcinoma usually metastasizes to the lungs, bones, and regional lymph nodes and rarely to the head and neck region (Som et al., 1987). Approximately 15\% of RCC metastasis is observed in the paranasal sinuses, larynx, jaws, temporal bones, thyroid gland, and parotid glands (Som et al., 1987). We presented a patient with RCC metastasis in the lower lip who underwent a nephrectomy for RCC previously.

\section{Case report}

A 65-year-old woman presented with a rapidly growing and intermittently bleeding lower lip mass for three weeks. Ten years ago, the patient underwent a right nephrectomy because of RCC. The patients received chemoradiotherapy three years ago due to lung metastasis on the left side, but treatment was discontinued after the patient was diagnosed with tuberculosis. The physical examination revealed a $2 \times 1 \mathrm{~cm}$ hemorrhagic, ulcerated mass on the lower lip' s left side. The mass was excised totally under local anesthesia. Histological examination via immunohistochemical staining identified the tumor as metastatic RCC (Fig. 1 and 2). The closest surgical margin distance of the tumor was $7 \mathrm{~mm}$. Twenty days after the surgical resection patient's general condition was impaired, he was brought to emergency department with unconsciousness. Multiple intracerebral metastases were detected in the brain magnetic resonance imaging, and the patient died in a month.

\section{Discussion}

RCC, also known as hypernephroma, is the most frequent urological malignancy in adults and has a male predominance (Gottlieb and Roland, 1998). It constitutes 3\% of adult malignancies and $90 \%-95 \%$ of neoplasms arising from the kidney (Gottlieb and Roland, 1998). Distant metastases commonly occur in $30 \%-40 \%$ of patients (Pritchyk et al., 2002). The most frequent metastasis sites are the lungs (76\%), regional lymph nodes $(66 \%)$, bone $(42 \%)$ and liver $(41 \%)$ (Pritchyk et al., 2002).

RCC is the third most common infraclavicular neoplasm that metastasizes to the head and neck following breast and lung carcinoma (Pritchyk et al., 2002). Approximately 15\% of RCC patients have extracranial head and neck metastases (Gottlieb and Roland, 1998). According to the literature, the rare RCC metastasis in head and neck regions include salivary glands, mandible, maxilla, nasal cavity, paranasal sinuses, nasopharynx, palate, orbita, thyroid, and parathyroid glands (Airoldi et al., 1995; Sabo et al., 2001; Pritchyk et al., 2002; Lang et al., 2003; Iesalnieks et al., 2007).

Lips are unusual sites for any metastasis development. A few cases of metastasis to the lips from the lung, gastric adenocarcinoma, breast, lymphoma, and kidneys had been reported previously (Pritchyk et al., 2002; Jatti et al., 2015). Also, intraoral RCC metastases affecting the tongue, palate, buccal mucosa, upper and lower lips, gingiva, and floor of the mouth had been reported previously (Susan et al., 1979; Corsi 
et al., 1994; Airoldi et al., 1995; Ficarra et al., 1996; Pritchyk et al., 2002; Lang et al., 2003; Makos and Psomaderis, 2009). Metastases of RCC are vascular and tend to bleed (Ishak et al., 2010). A clinic biopsy of the lesion could result in uncontrolled hemorrhage (Pritchyk et al., 2002). It was reported that solitary RCC metastatic lesions result in $41 \%$ survival at two years and $13 \%$ survival at five years, regardless of the time interval between nephrectomy and metastasis (Gttlieb and Roland, 1998). Renal cell carcinoma is traditionally described as a radioresistant tumor.

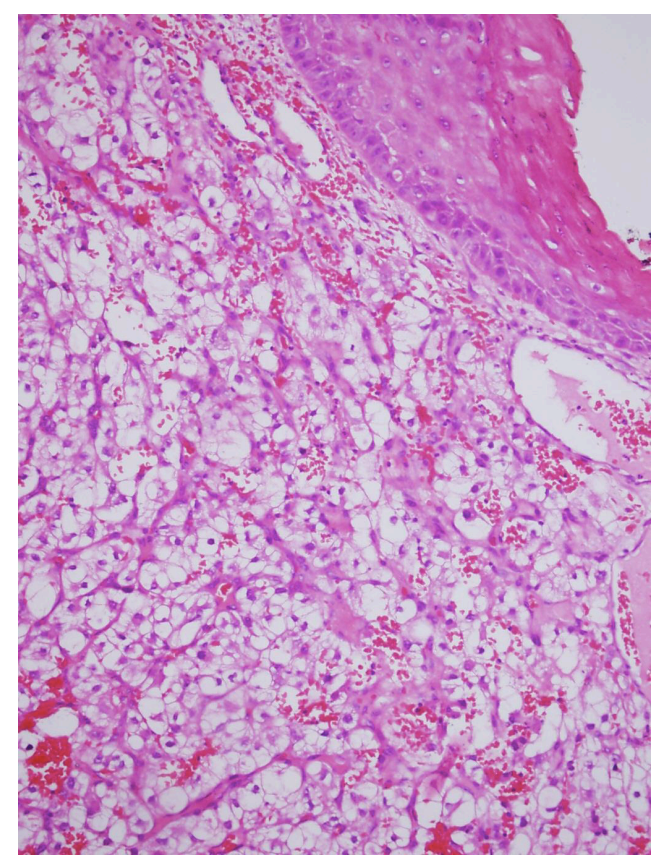

Fig. 1. Solid nest of epithelial cells with clear cytoplasm and small, round hyperchromatic nuclei under mucosa (H\&Ex200)

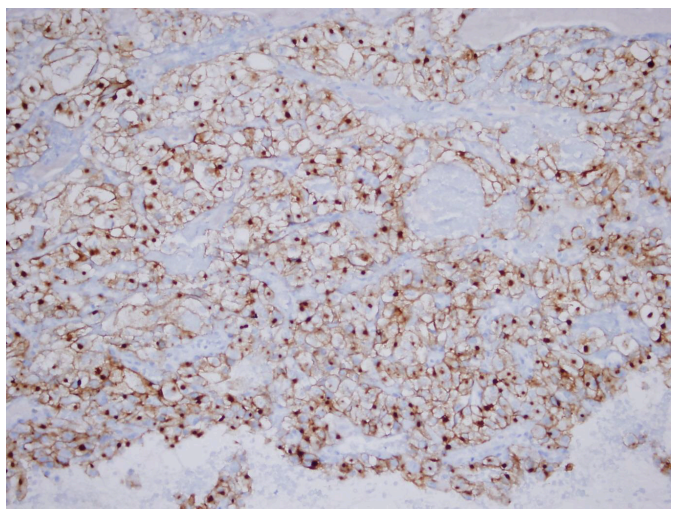

Fig. 2. Tumor cells are positive CD10 (DABx200)

Other forms of treatment have been advocated for metastatic RCC. Immunotherapy with interferon- $\alpha$ and interleukin-2 has been the mainstay of treatment for people with advanced and metastatic RCC. Recent advances in understanding the biology and genetics of RCC have led to several novel target approaches with higher response rates. Treatment with sunitinib, sorafenib, bevacizumab, erlotinib, and CCI-779 provided significant results regarding progression-free survival (Thompson Coon et al., 2009).

Renal cell carcinoma is the third most common infraclavicular neoplasm to metastasize to the head and neck regions. In patients with RCC, metastasis should be considered in the differential diagnosis of rapidly growing vascular lesions in the head and neck area. A biopsy of the lesion could result in uncontrolled hemorrhage. Resection of the lesion with wide margins is the recommended treatment method instead of incisional biopsy due to possible uncontrollable hemorrhage.

\section{Conflict of interest}

None to declare.

\section{Acknowledgments}

None to declare.

\section{References}

1. Airoldi, M., Succo, G., Valente, G., Cavalot, A., Gabriele, P., Bumma, C., 1995. Head and neck metastases of renal cancer after nephrectomy: A report of 2 cases. Tumori. 81, 213-214.

2. Corsi, A., Guerra, F., Grippaudo, G., Bosman, C., 1994. Oral metastasis of renal cell carcinoma. Report of case and critical evaluation of morphologic features for differential diagnosis. Pathologica. 86, 665-669.

3. Ficarra, G., Pierleoni, L., Panzoni, E., 1996. Metastatic renal cell carcinoma involving Wharton's duct: a case report. Oral. Surg. Oral. Med. Oral. Pathol. Oral. Radiol. Endod. 81, 580-583.

4. Gottlieb, M.D., Roland, J.T., 1998. Paradoxical spread of renal cell carcinoma to the head and neck. Laryngoscope. 108, 13011305.

5. Iesalnieks, I., Trupka, A., Raab, M., Glockzin, G., Woenckhaus, M., Schlitt, H.J., et al, 2007. Renal cell carcinoma metastases to the thyroid gland 8 cases reported. Thyroid. 17, 49-52.

6. Ishak, A.I., Pauzi, S.H., Masir, N., See, G.B., 2010. Multiple Metastatic Deposits in the Head and Neck Region from a Renal Cell Carcinoma Malaysian J. Med. Sci. 17(4), 71-74.

7. Jatti, D., Puri, G., Aravinda, K., Dheer, D.S., 2015. An atypical metastasis of renal clear cell carcinoma to the upper lip: A case report. J. Oral. Maxillofac. Surg. 73(2), 371, e1-6.

8. Lang, E.E., Patil, N., Walsh, R.M., Leader, M, Wals, M.A., 2003. A case of renal cell carcinoma metastatic to the nose and tongue. Ear Nose Throat J. 82, 382-383.

9. Makos, C.P., Psomaderis, K., 2009. A literature review in renal carcinoma metastasis to the oral mucosa and a new report of an epulis-like metastasis. J. Oral Maxillofac. Surg. 67, 653-660.

10. Pritchyk, K.M., Schiff, B.A., Newkirk, K.A., Krowiak, E., Deeb, Z.E., 2002. Metastatic renal cell carcinoma to the head and neck. Laryngoscope. 112, 1598-1602.

11. Sabo, R., Sela, M., Sabo, G., Herskovitz, P., Feinmesser, R., 2001. Metastatic hypernephroma to the head and neck: unusual case reports and review of the literature. J. Otolaryngol. 30,140-144.

12. Som, P.M., Norton, K.I., Shugar, J.M., Reede, D.L., Norton, L., Biller, H.F., et al, 1987. Metastatic hypernephroma to the head and neck. AJNR Am. J. Neuroradiol. 8(6), 1103-1106.

13. Susan, L.P., Daughtry, J.D., Stewart, B.H., Straffon, R.A.,1979. Palatal metastases in renal cell carcinoma. Urology. 13, 304-305.

14. Thompson Coon, J.S., Liu, Z., Hoyle, M., Rogers, G., Green, C., Moxham, T., et al, 2009. Sunitinib and bevacizumab for first-line treatment of metastatic renal cell carcinoma: A systematic review and indirect comparison of clinical effectiveness. Br. J. Cancer. 101(2), 238-243. 